\title{
Salmonella enterica serovar Typhimurium adhesion and cytotoxicity during epithelial cell stress is reduced by Lactobacillus rhamnosus GG Kristin M Burkholder and Arun K Bhunia*
}

\author{
Address: Molecular Food Microbiology Laboratory, Department of Food Science, 745 Agriculture Mall Drive, Purdue University, West Lafayette, \\ Indiana 47907-2009, USA \\ Email: Kristin M Burkholder - kburkhol@purdue.edu; Arun K Bhunia* - bhunia@purdue.edu \\ * Corresponding author
}

Published: 9 July 2009

Gut Pathogens 2009, I:14 doi:10.1/86/1757-4749-1-14

This article is available from: http://www.gutpathogens.com/content///I//4

(C) 2009 Burkholder and Bhunia; licensee BioMed Central Ltd.

This is an Open Access article distributed under the terms of the Creative Commons Attribution License (http://creativecommons.org/licenses/by/2.0), which permits unrestricted use, distribution, and reproduction in any medium, provided the original work is properly cited.

\begin{abstract}
Background: Physiological stressors may alter susceptibility of the host intestinal epithelium to infection by enteric pathogens. In the current study, cytotoxic effect, adhesion and invasion of Salmonella enterica serovar Typhimurium (S. Typhimurium) to Caco-2 cells exposed to thermal stress $\left(4{ }^{\circ} \mathrm{C}, \mathrm{I} \mathrm{h}\right)$ was investigated. Probiotic bacteria have been shown to reduce interaction of pathogens with the epithelium under non-stress conditions and may have a significant effect on epithelial viability during infection; however, probiotic effect on pathogen interaction with epithelial cells under physiological stress is not known. Therefore, we investigated the influence of Lactobacillus rhamnosus GG and Lactobacillus gasseri on Salmonella adhesion and Salmonella-induced cytotoxicity of Caco-2 cells subjected to thermal stress.
\end{abstract}

Results: Thermal stress increased the cytotoxic effect of both $S$. Typhimurium $(P=0.000 \mathrm{I})$ and nonpathogenic $E$. coli $\mathrm{K} I 2(\mathrm{P}=0.004)$ to Caco-2 cells, and resulted in greater susceptibility of cell monolayers to $S$. Typhimurium adhesion $(P=0.00 I)$. Thermal stress had no significant impact on inflammatory cytokines released by $\mathrm{Caco}-2$ cells, although exposure to $S$. Typhimurium resulted in greater than $80 \%$ increase in production of IL- 6 and IL-8. Blocking S. Typhimurium with anti-ShdA antibody prior to exposure of Salmonella decreased adhesion $(P=0.0 \mathrm{I})$ to non-stressed and thermal-stressed Caco-2 cells. Pre-exposure of Caco-2 cells to L. rhamnosus GG significantly reduced Salmonella-induced cytotoxicity $(P=0.00 \mathrm{I})$ and Salmonella adhesion $(P=0.00 \mathrm{I})$ to Caco2 cells during thermal stress, while $L$. gasseri had no effect.

Conclusion: Results suggest that thermal stress increases susceptibility of intestinal epithelial Caco-2 cells to Salmonella adhesion, and increases the cytotoxic effect of Salmonella during infection. Use of $L$. rhamnosus GG as a probiotic may reduce the severity of infection during epithelial cell stress. Mechanisms by which thermal stress increases susceptibility to $S$. Typhimurium colonization and by which L. rhamnosus GG limits the severity of infection remain to be elucidated.

\section{Background}

Salmonella enterica are important facultative intracellular pathogens that cause gastroenteritis in humans [1]. The diverse Salmonella genus contains over 2500 serotypes [2], all of which are potentially pathogenic to humans [3].
Specifically, Salmonella enterica serovar Typhimurium ( $S$. Typhimurium) is implicated in human foodborne illnesses and often enters the human food supply via contamination of poultry, pork, beef and dairy products, and nuts such as peanuts and pistachios. In recent years, anti- 
biotic-resistant strains of Salmonella have emerged, and salmonellosis caused by multi-drug resistant $S$. Newport and S. Typhimurium DT104 has caused great public health concern [4-6].

Adhesion of Salmonella to the intestinal epithelial surface is a key first step in pathogenesis and is central to its colonization of the intestine [7]. Although Salmonella can colonize a healthy host, the greatest risk for intestinal infection by enteric pathogens may occur during periods of physiological stress. In vivo animal studies have shown that during periods of stress, susceptibility to Salmonella colonization and infection increases [8-10]. Less is known of how physiological stress may influence the interaction of Salmonella with the human intestinal epithelium, although it is likely to follow a similar trend as other animal models. Proposed mechanisms for increased Salmonella colonization during stress have largely focused on the deleterious effect of stress on host immunity. While impaired immune function certainly contributes to stressrelated infection, little information exists about the influence of stress on susceptibility of epithelial cells to infection. The intestinal epithelium is a crucial, but thin, barrier, which is susceptible to perturbation by stress $[11,12]$. In particular, epithelial damage elicited by stress may expose or cause apical secretion of extracellular matrix proteins such as fibronectin [13], which serves as receptor for the MisL and ShdA adhesion proteins of $S$. Typhimurium [14,15].

Recent research has indicated that most physiological and psychological stressors have an impact on gut health and susceptibility to enteric pathogens [16]. For the current study, we used high temperature $\left(41^{\circ} \mathrm{C}, 1 \mathrm{~h}\right)$ to examine the influence of stress on Salmonella colonization of cultured intestinal epithelial cells and the effectiveness of probiotic Lactobacilli for altering the outcome of infection. Core temperatures ranging from $39^{\circ} \mathrm{C}$ to $42.5^{\circ} \mathrm{C}$ are physiologically relevant and have been reported in humans suffering from mild to severe thermal stress [12]. The deleterious effects of thermal stress are first manifested in the gut [12] in humans and animals, and we and others have shown that high temperature stress damages the intestinal epithelium using animal and cell culture models [11,17-19]. Therefore, we chose to use thermal stress as a model physiological stressor that, like other physiological or psychological stressors, can alter normal intestinal homeostasis and may influence the outcome of infection. Specifically, stress due to high temperature $\left(39^{\circ} \mathrm{C}-42^{\circ} \mathrm{C}\right)$ can elicit enterocyte membrane damage or death $[11,18]$, alter of normal villus/crypt structure $[17,18]$, impair tight junction integrity [20], and may enhance susceptibility to colonization and infection by enteric microorganisms. Greater vulnerability to enteric microbes is demonstrated by increased LPS concentration in the blood following thermal stress $[19,21]$, and indi- cates that a compromised gut barrier may lead to opportunistic infection. However, little information exists on the influence of thermal stress on epithelial susceptibility to pathogen binding and cytotoxicity.

Inhibition of pathogen adhesion to the intestinal epithelium may prevent colonization and limit opportunity for systemic infection $[8,22]$. Certain probiotic bacteria, including Lactobacillus and Bifidobacteria, may be effective in ameliorating negative intestinal effects of stress $[23,24]$ or preventing adhesion and invasion by enteric pathogens, including Salmonellae [25-29]. Although the exact mechanism of action is unknown, probiotics could reduce intestinal infections by competing with pathogens for binding sites on the intestinal wall, competing for nutrients within the intestinal lumen, producing antibacterial compounds or lactic acid, or by stimulating the host immune system [30-34]. Despite numerous studies which demonstrate antipathogenic properties of probiotics, great variability exists in their reported effectiveness in reducing intestinal infection $[23,35]$ and this variability may depend on which probiotic organism is used, as well as health status of the host. In fact, recent studies suggest that probiotics may be most effective when normal intestinal homeostasis is perturbed, particularly during periods of stress [16]. Therefore, in the current study, we examined the influence of stress on colonization of $S$. Typhimurium and epithelial membrane damage, and determined the influence of L. rhamnosus GG and L. gasseri on the Salmonella-epithelial interaction.

\section{Results \\ Influence of thermal stress on bacterial adhesion, invasion, and cytotoxic effects}

In vitro cell culture experiments were conducted to determine the effect of thermal stress on cellular susceptibility to bacterial attachment, invasion and on lactate dehydrogenase (LDH) release (\% cytotoxicity) from monolayers exposed to bacteria. Subjecting Caco-2 cells to thermal stress $\left(41^{\circ} \mathrm{C}\right)$ for $1 \mathrm{~h}$ prior to bacterial exposure increased adhesion of $S$. Typhimurium by more than 1.7 -fold $(\mathrm{P}=$ $0.001)$, whereas adhesion of nonpathogenic E. coli K12 was unchanged (Table 1, Fig 1). Bacterial invasion of Caco- 2 cells was not influenced by thermal stress (Table 1 , Fig 1). Greater adhesion of nonpathogenic E. coli K12 than $S$. Typhimurium was observed only at $37^{\circ} \mathrm{C}$, and is likely due to expression of pili and other adhesion molecules which enable intestinal commensal organisms to colonize without causing infection [36].

LDH release (percent cytotoxicity) increased by over 3.5fold $(\mathrm{P}=0.0001)$ when Caco-2 cells were subjected to both thermal stress and $S$. Typhimurium infection compared to unstressed, uninfected cells (Table 1). Exposure to E. coli $\mathrm{K} 12$ also induced cytotoxicity in thermallystressed cells $(P=0.0004)$, albeit at a lower level than 


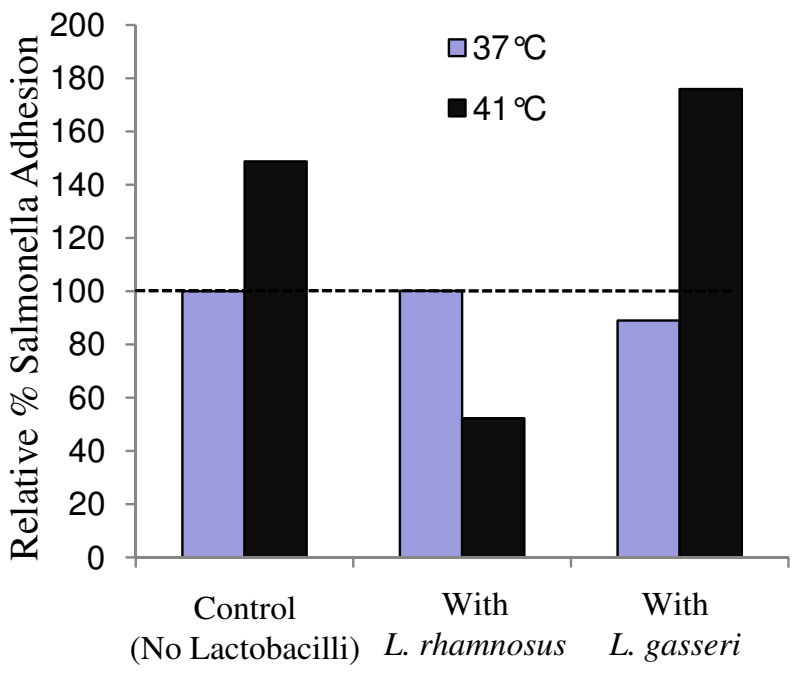

Figure I

Effect of pre-exposure of Lactobacillus rhamnosus GG or $L$. gasseri to thermal-stressed $\left(4 I^{\circ} \mathrm{C}, \mathrm{I} \mathrm{h}\right) \mathrm{Caco}-2$ cells on adhesion of Salmonella enterica serovar Typhimurium. Percent adhesion values are given relative to the adhesion of S. Typhimurium to Caco-2 cells at $37^{\circ} \mathrm{C}$ without exposure to Lactobacilli, which were taken as $100 \%$. The percent error rates for treatments are as follows: Control (no Lactobacilli) at $37^{\circ} \mathrm{C}-2.12 \%$, Control (no Lactobacilli) at $41^{\circ} \mathrm{C}-1.89 \%$, with $L$. rhamnosus at $37^{\circ} \mathrm{C}-2.9 \%$, with $L$. rhamnosus at $41^{\circ} \mathrm{C}-4.43 \%$, with $L$. gasseri at $37^{\circ} \mathrm{C}-7.2 \%$, with L. gasseri at $4 \mathrm{I}^{\circ} \mathrm{C}-10.8 \%$.

observed with $S$. Typhimurium. Since high temperature stress in absence of bacteria induced a more modest increase $(P=0.005)$ in LDH release (Table 1 , Fig 2$)$, it is likely that exposure of stressed Caco-2 cells to bacterial products led to induction of the cytotoxic response. Interestingly, exposure to L. rhamnosus or L. gasseri did not induce a significant change in LDH release at either temperature, suggesting that bacteria-induced cytotoxicity observed with Salmonella and E. coli may be specifically due to Gram-negative microbial products (Table 1).

\section{Adhesion and cytotoxic effect of S. Typhimurium on thermal-stressed Caco-2 cells pre-exposed to Lactobacilli} We sought to determine the influence of probiotics $L$. rhamnosus and L. gasseri on adhesion and cytotoxic effect of Salmonella to intestinal cell lines under normal and stress conditions by exposing Caco- 2 monolayers to $L$. rhamnosus or L. gasseri for $1 \mathrm{~h}$ prior to stress and/or infection. L. rhamnosus did not alter adhesion of Salmonella to unstressed cells, but a significant reduction $(P=0.001)$ in Salmonella adhesion was observed in thermal-stressed cells that had been pre-exposed to L. rhamnosus (Fig 1). Similarly, L. rhamnosus offered a protective effect against cytotoxicity induced by Salmonella and E. coli K12 in-thermal stressed Caco-2 monolayers, reducing cytotoxicity by over 3-fold and 1.5-fold, respectively (Fig 2). In contrast, L. gasseri, another probiotic strain [37], did not protect Caco-2 cells from Salmonella adhesion (Fig 1) or Salmonella or E. coli-induced cytotoxicity (Fig 2). The differences in protection offered by L. rhamnosus and L. gasseri against Salmonella adhesion and bacterial-induced cytotoxicity may be due to their own relative adhesion levels during thermal stress; at $41^{\circ} \mathrm{C}$, adhesion of L. rhamnosus GG increased $(\mathrm{P}=0.03)$, whereas adhesion of $L$. gasseri decreased $(P=0.02)$ (Table 1$)$.

\section{Adhesion of S. Tyhpimurium after blocking bacterial surface with anti-ShdA antibody}

Since S. Typhimurium ShdA aids in epithelial adhesion by binding to host fibronectin [14], we tested the influence of ShdA in adhesion during normal and stress conditions, when epithelial fibronectin may be more available. Blocking of Salmonella ShdA with anti-ShdA antibody prior to infection of Caco- 2 cells resulted in a reduction in Salmonella binding from 5.9 to $3.7 \%(\mathrm{P}=0.01)$ in unstressed cells and from $14.9 \%$ to $9.2 \%(\mathrm{P}=0.003)$ in thermalstressed monolayers (fig 3).

\section{Transmission electron microscopy of thermal-stressed Caco-2 cells infected with $S$. Typhimurium}

TEM was used to visualize the Caco-2 cell surface architecture before and after thermal stress, as well as during the

Table I: Adhesion, invasion and cytotoxic effect of Salmonella enterica serovar Typhimurium and E. coli $\mathrm{KI} 2$ on thermal-stressed (4I ${ }^{\circ} \mathrm{C}$ for I h) Caco-2 cells

\begin{tabular}{|c|c|c|c|c|c|c|}
\hline \multirow[t]{2}{*}{ Bacteria } & \multicolumn{2}{|c|}{$\%$ Adhesion } & \multicolumn{2}{|c|}{$\%$ Invasion } & \multicolumn{2}{|c|}{ \% Cytotoxicity } \\
\hline & $37^{\circ} \mathrm{C}$ & $41^{\circ} \mathrm{C}$ & $37^{\circ} \mathrm{C}$ & $41^{\circ} \mathrm{C}$ & $37^{\circ} \mathrm{C}$ & $41^{\circ} \mathrm{C}$ \\
\hline S. Typhimurium & $5.63 \pm 1.19 \mathrm{bB}$ & $16.39 \pm 5.68^{\mathrm{aA}}$ & $0.09 \pm 0.01 \mathrm{~A}$ & $0.08 \pm 0.01 \mathrm{~A}$ & $8.32 \pm 1.36^{\mathrm{bA}}$ & $30.52 \pm 1.08^{\mathrm{aA}}$ \\
\hline E. coli KI2 & $13.40 \pm 1.07 \mathrm{~A}$ & $15.10 \pm 1.45^{A}$ & $0.003 \pm 0^{B}$ & $0.003 \pm 0^{B}$ & $8.04 \pm 1.43^{\mathrm{bA}}$ & $20.68 \pm 1.43^{\mathrm{aB}}$ \\
\hline L. rhamnosus GG & $1.82 \pm 0.12^{b}$ & $5.28 \pm 0.49 a$ & NT & NT & $5.31 \pm 0.96^{B}$ & $7.32 \pm 4.6 C$ \\
\hline L. gasseri & $4.47 \pm 1.13^{a}$ & $1.58 \pm 0.34^{b}$ & NT & NT & $6.05 \pm 0.5^{B}$ & $5.52 \pm 1.14^{C}$ \\
\hline No bacteria & NT & NT & NT & NT & $0^{\mathrm{bC}}$ & $9.46 \pm 1.08^{\mathrm{aD}}$ \\
\hline
\end{tabular}

Values represent 12 wells per treatment. Rows labeled with $(a, b)$ and columns labeled with $(A, B, C)$ bearing different superscripts within events are significantly different according to Duncan's test $(P<0.05)$. NT, not tested 
A

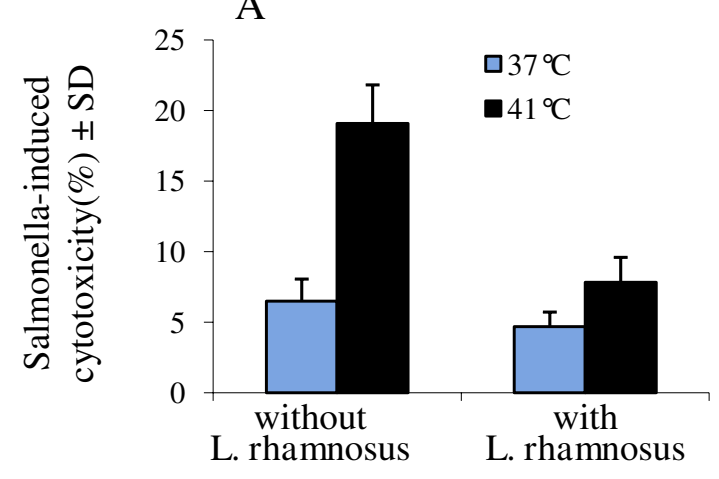

C

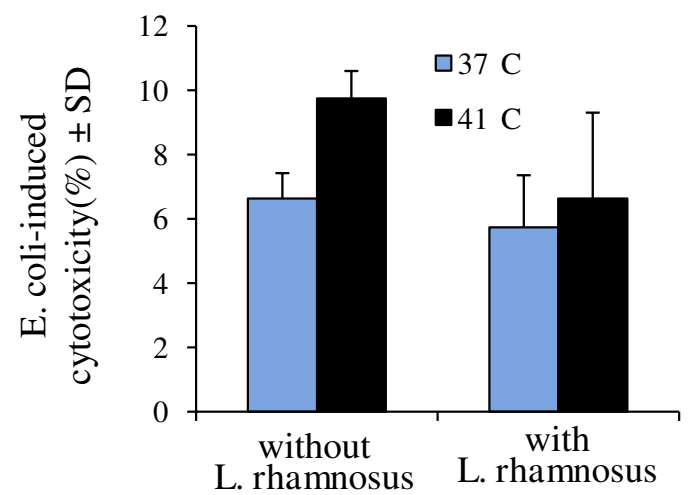

B

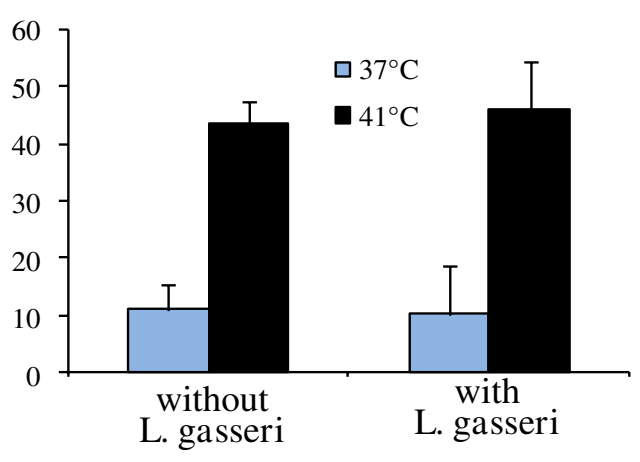

$\mathrm{D}$

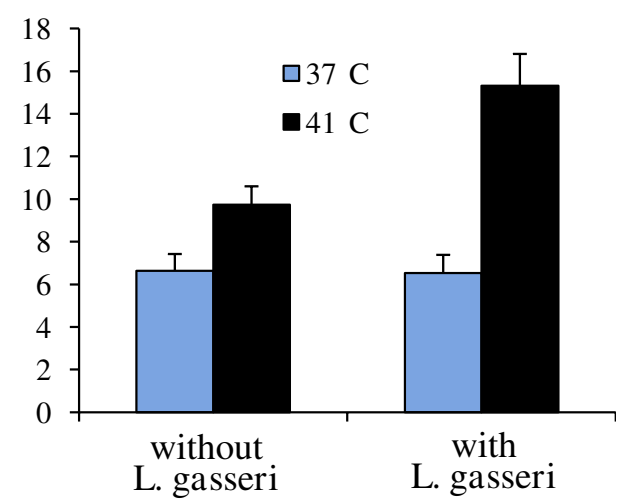

Figure 2

Effect of pre-exposure of (A, C) Lactobacillus rhamnosus GG, (B, D) L. gasseri to thermal-stressed $\left(4 I^{\circ} \mathrm{C}, \mathrm{I} \mathrm{h}\right)$ or untreated $\left(37^{\circ} \mathrm{C}\right)$ Caco-2 cells on cytotoxicity induced by Salmonella enterica serovar Typhimurium or E. coli KI 2 .

interaction between $S$. Typhimurium and the thermalstressed Caco- 2 cell surface. In Caco- 2 cells with no bacterial exposure $\left(37^{\circ} \mathrm{C}\right.$ and $41^{\circ} \mathrm{C}$ treatments), cells exhibited microvilli and surface projections characteristic of actively growing cells undergoing pinocytosis (Fig 4A, B) [38], indicating that the thermal stress conditions were not sufficient to alter cell surface morphology. In unstressed Caco-2 cells, $S$. Typhimurium were observed in close proximity to the eukaryotic cells (Fig 4C), but more bacteria were seen in contact with the Caco-2 cells when cells had been subjected to high temperature (Fig 4D).

\section{Influence of thermal stress and S. Typhimurium infection on cytokine expression in Caco-2 cells}

Since host cytokines can affect intestinal homeostasis $[39,40]$, we determined the influence of thermal stress and $S$. Typhimurium infection on expression of cytokines by Caco- 2 cells. As reported by others, $S$. Typhimurium infection induced greater than $80 \%$ increase in expression of IL- 6 and IL-8 $[41,42]$, but subjecting Caco- 2 cells to thermal stress alone $\left(41^{\circ} \mathrm{C}, 1 \mathrm{~h}\right)$ did not alter cytokine expression (Fig 5).

\section{Discussion}

Stress, whether physical or psychological, can have a notable effect on host physiology, with the earliest and greatest impact occurring in the gastrointestinal tract [43]. In vitro work has shown deleterious effects of stress on intestinal integrity $[16,18]$, which may enhance pathogen adherence to the intestinal epithelium. Interestingly, some reports show that multiple exposures to mild stress can induce a cytoprotective effect in intestinal epithelial cells against future, more severe, stressors, likely due to induction of the heat shock response [44]. However, in vitro models have shown that acute stress can decrease transepithelial resistance of epithelial cells [43,45], increase expression or secretion of proteins such as fibronectin [13] or heat shock proteins $[46,47]$, which are targeted as receptors by some enteric pathogens $[13,48,49]$. While in vivo studies with food producing animals have associated 


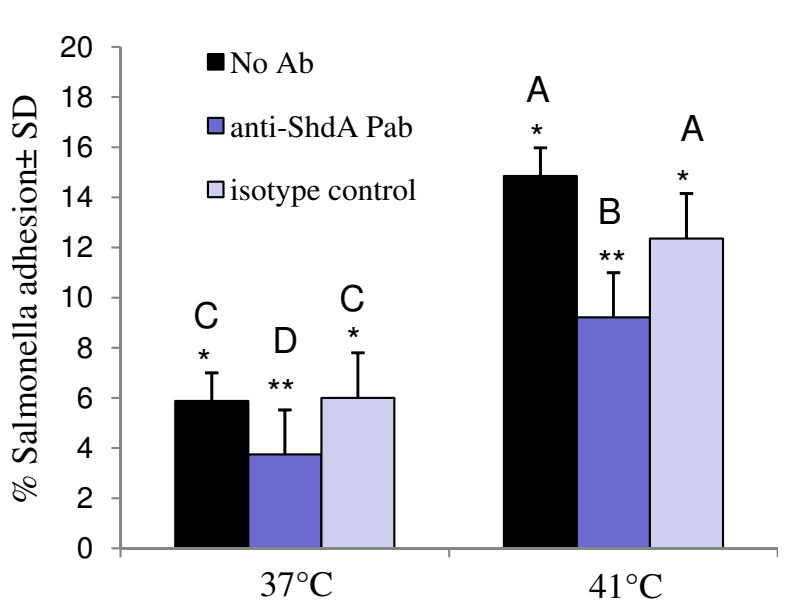

Figure 3

Influence of anti-ShdA antibody in adhesion of $S$. Typhimurium to unstressed $\left(37^{\circ} \mathrm{C}\right)$ or thermalstressed $\left(4 I^{\circ} \mathrm{C}, \mathrm{I} \mathrm{h}\right) \mathrm{Caco}-2$ cells. Prior to infection of Caco-2 cell monolayers, $\mathrm{S}$. Typhimurium cells were treated with anti-ShdA antibody, isotype control anti-Salmonella polyclonal antibody or left untreated. Bars marked with different letters $(A, B, C, D)$ are significantly different at $P<0.05$.

stress with increased intestinal colonization and shedding of Salmonella and other enteric pathogens $[9,10]$, less is known of how stress may influence Salmonella interaction with the human intestinal epithelium, or how probiotic bacteria may mediate this interaction.

Here we report increased binding of $S$. Typhimurium to Caco- 2 cells following $1 \mathrm{~h}$ of thermal stress $\left(41^{\circ} \mathrm{C}\right)$ (Table 1, Fig 1). Epithelial cells may be subjected to stress in a variety of ways, and it is worth noting that bacterial infection itself may serve as a stressor to host tissues. A natural $S$. Typhimurium infection can induce fever in humans and animals [50,51]. Little information exists on the influence of fever on epithelial colonization by Salmonella, and although many systemic host factors are involved in the fever response that cannot be accounted for in a cell culture model, our data suggests that high temperature may influence epithelial susceptibility for infection.

Thermal stress alone elicited a mild increase in LDH release ( $9.46 \%$ cytotoxicity) from Caco-2 cells, agreeing with previous reports of epithelial cell damage induced by temperatures near $41^{\circ} \mathrm{C}$ [52]. However, transmission electron micrographs showed that this heat treatment alone was not sufficient to cause discernable changes in epithelial structure (Fig 4A, B). However, LDH release was greatest when stressed cells were infected with $S$. Typhimurium and to a lesser extent following exposure to nonpathogenic E. coli K12 (Table 1). The high level of

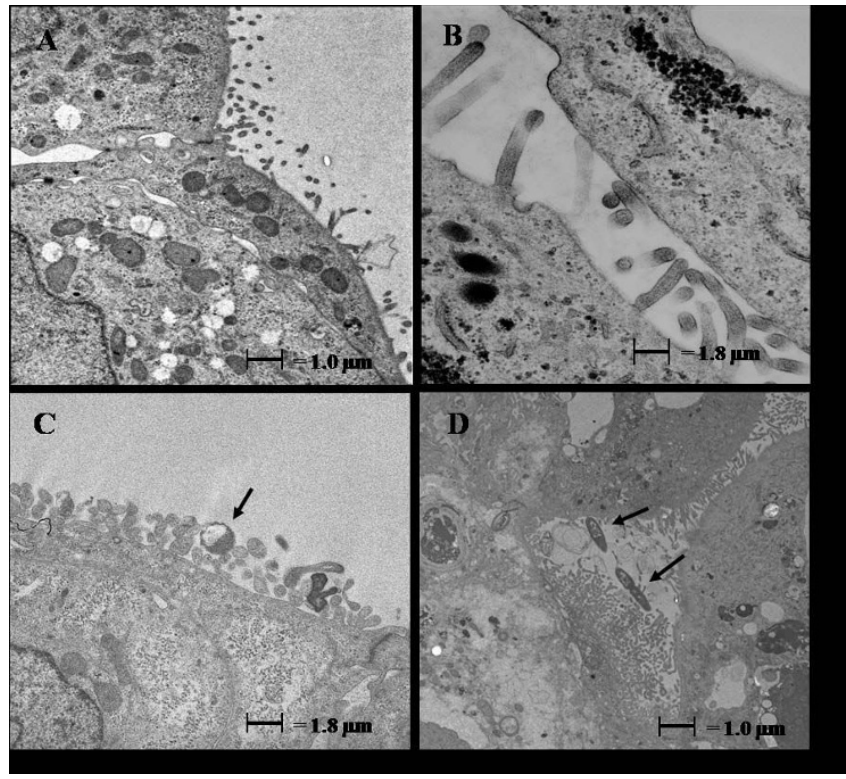

Figure 4

Transmission electron micrograph of Caco-2 cells following thermal stress and Salmonella enterica serovar Typhimurium exposure. (A) Caco-2 cells with no heat treatment and no added bacteria, (B) Caco-2 cells after thermal stress $\left(4 I^{\circ} \mathrm{C}, \mathrm{I} h\right),(\mathrm{C})$ non thermal-stressed Caco-2 cells exposed to $S$. Typhimurium ( $10^{6} \mathrm{cfu} / \mathrm{ml}$ for I h), and (D) thermal-stressed Caco-2 cells exposed to $S$. Typhimurium $\left(10^{6} \mathrm{cfu} / \mathrm{ml}\right.$ for I h). Arrows indicate S. Typhimurium cells.

cytotoxicity observed during infection with $S$. Typhimurium was likely due to membrane damage elicited by enterotoxins [53] (Table 1). Exposure of Caco-2 cells to $L$. rhamnosus or L. gasseri did not induce LDH release, suggesting that Gram-negative bacterial products, absent in Lactobacilli, may have enhanced the cytotoxic effect of high temperature. Interestingly, others have reported potential cytoprotective effects of Lactobacilli on intestinal epithelial cells $[54,55]$, and exposure to these probiotics may protect the epithelium against negative effects of physiological stress or infection $[38,56]$.

We also tested the influence of high temperature and Salmonella exposure on cytokine expression in Caco- 2 cells, since certain cytokines can alter gut integrity and influence the outcome of infection $[32,39,40]$. As reported by others, Salmonella infection significantly increased expression of IL- 6 and IL-8 [41,42]. However, we found no effect of thermal stress (Fig 5) on cytokine levels, indicating that alteration of epithelial cytokine production is not a likely mechanism by which stress affects intestinal susceptibility to $S$. Typhimurium colonization.

Initial adhesion to the intestine is the critical first step in establishing colonization or infection of the host [7]. Recent studies have demonstrated the importance of 


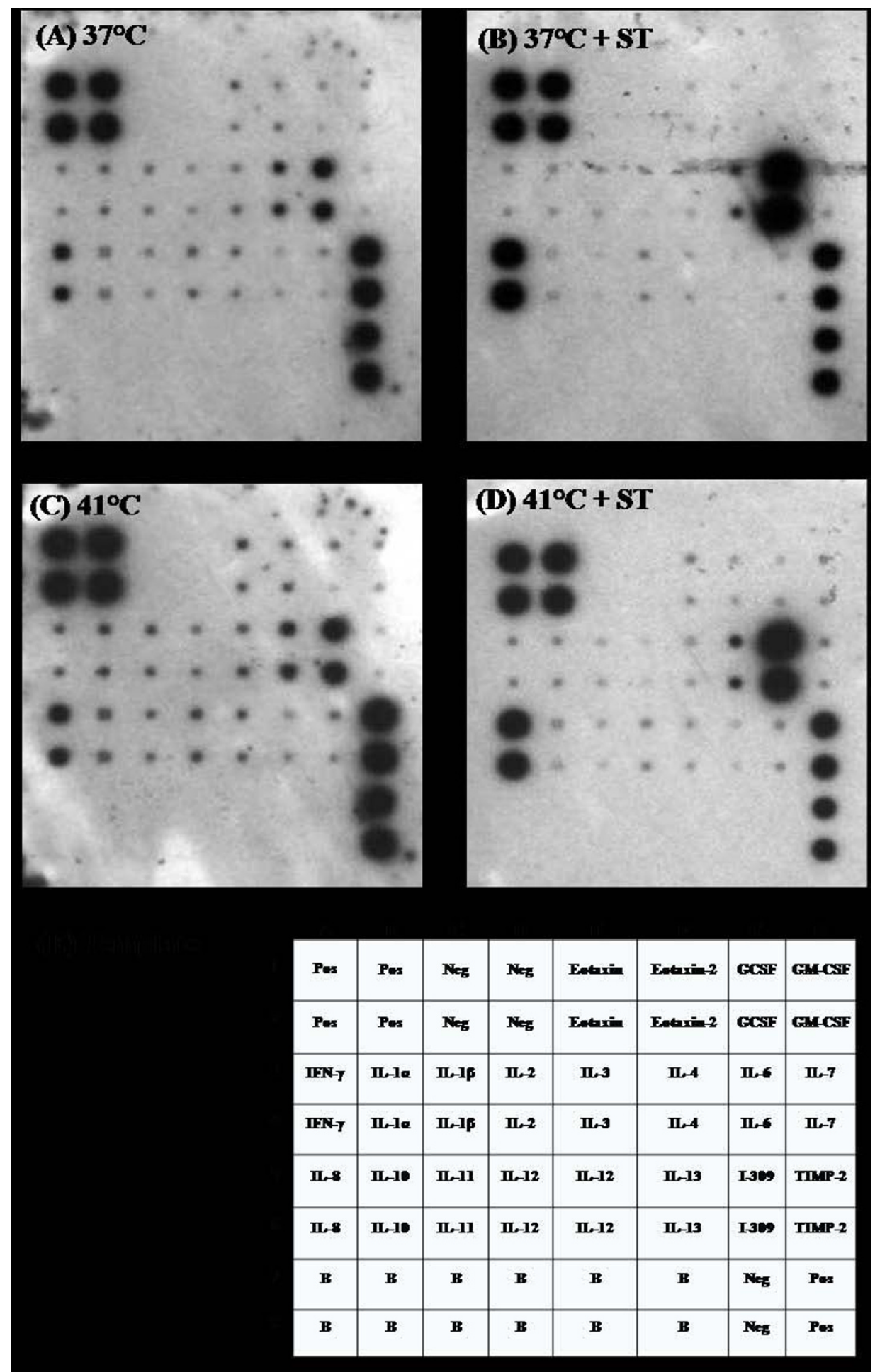

Figure 5

Immunoblot cytokine array analysis of Caco-2 cells held at (A) $37^{\circ} \mathrm{C}$, or exposed to (B) S. Typhimurium (ST) for I h at $37^{\circ} \mathrm{C}$, (C) $4 I^{\circ} \mathrm{C}$ thermal stress for I h, or (D) $4 I^{\circ} \mathrm{C}$ thermal stress for I h followed by I h of S. Typhimurium exposure. (E) Template showing the position of different cytokines. Pos, positive control; Neg, negative control; B, blank; GCSF, granulocyte colony stimulating factor; GM-CSF, granulocyte monocyte-colony stimulating factor; I-309, a CC chemokine; TIMP-2, tissue inhibitor of metalloproteinase-2. 
genes encoded on SPI3 in intestinal colonization of $S$. Typhimurium. SPI3-encoded T5SS (Type 5 Secretion System) pathway members MisL and ShdA were shown to bind to intestinal fibronectin in the mouse and mediate persistent $S$. Typhimurium colonization $[14,15]$. Disturbance of the intact epithelial barrier by stress or disease may increase exposure of basolateral proteins such as fibronectin, and may increase opportunity for pathogen binding. In the current study, we used a ShdA-specific antibody to block the ShdA protein on the surface of $S$. Typhimurium prior to conducting adhesion assays. The preliminary data showed that blocking ShdA reduced $S$. Typhimurium adhesion to normal and stressed Caco-2 cells, confirming that ShdA is also important for binding to human intestinal cells. While treating Salmonella with the anti-ShdA antibody did significantly reduce adhesion to thermal-stressed monolayers, adhesion after antibody treatment was still greater than that observed in unstressed cells. This indicates that while fibronectin exposure may play an important role in Salmonella colonization during stress and non-stress conditions, it is not the only factor involved in promoting colonization during epithelial cell stress. Indeed, a variety of pili and adhesion molecules also contribute to Salmonella binding and invasion during normal host condition [57] and are likely to promote binding when intestinal homeostasis is perturbed [58].

Previous reports have demonstrated the ability of probiotic bacteria to decrease pathogen binding and ameliorate mucosal damage elicited by infection. We recently showed that Lactobacillus bulgaricus inhibits binding and cytotoxic effect of Clostridium difficile with a Caco-2 cell model [59]. In addition, probiotics Streptococcus thermophilus and Lactobacillus acidophilus limited adhesion and invasion of enteroinvasive E. coli, and increased transepithelial resistance and tight junction integrity during infection [28]. Exposing epithelial cells to Lactobacillus casei prior to infection with adherent-invasive E. coli reduced adhesion of the pathogen by $73 \%$ [25].

In the current study, we examined the influence of $L$. rhamnosus GG and L. gasseri on Salmonella infection during acute epithelial stress. We chose these organisms because numerous reports indicate their effectiveness as probiotics, by improving epithelial integrity during infection $[60,61]$, and by limiting pathogen binding through either direct competition or by lactic acid production $[38,62]$. Here, we demonstrate that L. rhamnosus GG significantly reduced the cytotoxic effect of Salmonella in thermal-stressed Caco-2 cells, which agrees with other reports of the effectiveness of this probiotic in improving mucosal integrity and epithelial cell health during infection or exposure to toxins $[60,63]$. We also observed that L. rhamnosus significantly decreased Salmonella adhesion to stressed Caco-2 cells, but did not alter binding to unstressed cells (Fig 1C). Unlike L. rhamnosus, L. gasseri neither protected Caco-2 cells from the cytotoxic effect of high temperature and $S$. Typhimurium, nor altered adhesion of Salmonella. In contrast to our data, others found that both L. rhamnosus GG and L. gasseri limited adhesion of Salmonella [61] and E. coli $[38,64]$ to unstressed host cells. These discrepancies could be due to differences in the specific strains of L. gasseri or L. rhamnosus used in those studies, or to differences in the dose of probiotic or pathogen applied in the infection studies.

\section{Conclusion}

All together, our data indicate that physiological stress can increase epithelial susceptibility to $S$. Typhimurium adhesion and Salmonella-induced cytotoxicity. We show that $L$. rhamnosus GG may serve to protect against $S$. Typhimurium infection during periods of stress, by using some unique mechanism which is not employed by L. gasseri. Future work will focus on understanding what specific changes occur in the host epithelium during acute stress that promotes Salmonella binding, and how L. rhamnosus GG limits this binding and reduces host cell damage during infection.

\section{Methods}

\section{Bacterial strains and growth conditions}

Salmonella enterica serovar Typhimurium Copenhagan and Escherichia coli K12 were from our culture collection. E. coli $\mathrm{K} 12$ was used as a Gram-negative, nonpathogenic control. Lactobacillus rhamnosus strain GG and L. gasseri 1 SL4 were purchased from American Type Culture Collection (ATCC, Manassas, VA), and were indigenous human intestinal species that have been identified as potential probiotic organisms $[38,60,65]$.

$S$. Typhimurium and E. coli K12 stock cultures were grown in Luria Bertani (LB) broth and stored at $-20^{\circ} \mathrm{C}$ with the addition of $20 \%$ (vol $/ \mathrm{vol}$ ) glycerol. Cultures were grown statically overnight in LB broth at $37^{\circ} \mathrm{C}$, transferred twice to fresh LB broth and grown overnight for the Caco- 2 cell culture assays. Lactobacilli were grown in deMann-Rogosa-Sharpe (MRS) broth and stored at $-20^{\circ} \mathrm{C}$ with the addition of $20 \%$ ( $\mathrm{vol} / \mathrm{vol}$ ) glycerol. For active cultures, they were grown statically overnight in MRS broth at $37^{\circ} \mathrm{C}$ in microaerophilic atmosphere $\left(7 \% \mathrm{CO}_{2}\right)$, transferred twice to fresh MRS broth and grown overnight for the cell culture assays. All bacterial cells were harvested by centrifugation $\left(1,469 \times \mathrm{g}\right.$ for $15 \mathrm{~min}$ at $\left.4^{\circ} \mathrm{C}\right)$, then washed three times in $0.02 \mathrm{M}$ sterile phosphate buffered saline, $\mathrm{pH} 7.2$ (PBS) and resuspended to a concentration of approximately $1 \times 10^{8} \mathrm{cfu} / \mathrm{ml}$ in PBS.

\section{Cultured cell lines}

The Caco-2 (HTB37) human colon adenocarcinoma cell line (ATCC, Manassas, VA) was routinely cultured in Dulbeccos' Modified Eagles' Medium (DMEM; Sigma) with 
$10 \%$ (vol/vol) fetal bovine serum (FBS; Sigma). Cells were seeded in 24-well tissue culture dishes (Corning Life Sciences, New York, USA) or on 12-mm etched glass coverslips (EM Sciences, Fort Washington, Pa.) and grown to confluence at $37^{\circ} \mathrm{C}$ under $7 \% \mathrm{CO}_{2}$.

\section{Cytotoxicity Assay}

A cytotoxicity assay was used to quantify cell damage that occurred due to thermal stress or in the presence of pathogenic or probiotic bacteria. Cytotoxicity was determined using the Cytotoxicity Detection Kit (Roche Applied Science; Indianapolis, IN) which measures lactate dehydrogenase $(\mathrm{LDH})$ release from the cytosol of damaged Caco2 cells into the supernatant $[66,67]$. Two controls were included for calculation of percent cytotoxicity. Low controls consisted of supernatant from non-stressed Caco-2 cells with no exposure to bacteria. High controls were from cells treated with $1 \%$ Triton X-100 for one minute. All supernatants were centrifuged $(800 \times \mathrm{g}$ for $5 \mathrm{~min})$ to remove bacterial and eukaryotic cells. A $100 \mu \mathrm{l}$ aliquot of each sample was dispensed in triplicate wells of a 96 well plate and LDH activity was determined as per manufacturer's protocol (Roche).

\section{Adhesion, invasion and cytotoxicity analyses with thermal- stressed intestinal cell line}

The influence of thermal stress on susceptibility of Caco2 cells to bacterial attachment and cytotoxicity was evaluated. Wells containing confluent cell monolayers were washed three times with FBS-free DMEM and subjected to thermal stress $\left(41^{\circ} \mathrm{C}\right.$ for $\left.1 \mathrm{~h}\right)$. After heat stress, Caco-2 cells were inoculated with washed bacterial suspensions (S. Typhimurium or E. coli K12) at a multiplicity of exposure (MOE) of about $100: 1$, and were incubated at $37^{\circ} \mathrm{C}$ or $41^{\circ} \mathrm{C}$ for $1 \mathrm{~h}$ in $7 \% \mathrm{CO}_{2}$ atmosphere. Media from each well were removed and analyzed for LDH activity (\% cytotoxicity) as above. To analyze bacterial attachment, the same wells containing Caco- 2 cells were washed 5 times each with $1 \mathrm{ml}$ of cell-PBS $(137 \mathrm{mM} \mathrm{NaCl}, 5.4 \mathrm{mM} \mathrm{KCl}$, $3.5 \mathrm{mM} \mathrm{Na}_{2} \mathrm{HPO}_{4}, 4.4 \mathrm{mM} \mathrm{NaH} \mathrm{PO}_{4}, 11 \mathrm{mM}$ glucose, $\mathrm{pH}$ $7.2)$ to remove non-adherent bacterial cells [68]. Monolayers were treated with $0.1 \%$ Triton $\mathrm{X}-100$ for $10 \mathrm{~min}$, serially diluted and plated on LB agar for enumeration of S. Typhimurium and E. coli K12.

To quantify bacterial invasion, monolayers were first exposed to Salmonella for $1 \mathrm{~h}$, washed and then treated with $1 \mathrm{ml}$ of gentamicin $(100 \mu \mathrm{g} / \mathrm{ml})$ suspended in DMEM for $1 \mathrm{~h}$. Media were removed, cells were washed 5 times with cell PBS, treated with $0.1 \%$ Triton X-100 for 10 min, serially diluted and plated on LB agar as above.

\section{Influence of pre-exposure to Lactobacilli on adhesion and cytotoxicity of S. Typhimurium to Caco-2 cells}

The influence of L. rhamnosus GG and L. gasseri on susceptibility of Caco-2 cell line to $S$. Typhimurium attachment was determined under normal $\left(37^{\circ} \mathrm{C}\right)$ and thermal stress $\left(41^{\circ} \mathrm{C}\right)$ conditions. L. rhamnosus or L. gasseri were added at a MOE of $100: 1$ to Caco- 2 cells at $37^{\circ} \mathrm{C}$ for $1 \mathrm{~h}$. Caco- 2 cells with lactobacilli were held at $37^{\circ} \mathrm{C}$ or $41^{\circ} \mathrm{C}$ for an additional hour, and a $0.1 \mathrm{ml}$ aliquot of $S$. Typhimurium $\left(4 \times 10^{6} \mathrm{cfu} / \mathrm{ml}\right)$ was added to wells with an MOE of about $4: 1$, and plates were incubated at $37^{\circ} \mathrm{C}$ or $41^{\circ} \mathrm{C}$ for an hour. Media were removed from experimental wells to analyze for LDH activity and adhesion of Salmonella was determined as above.

\section{Role of ShdA in adhesion of S. Typhimurium}

Prior to addition of $S$. Typhimurium to Caco-2 cells, bacteria were incubated for $1 \mathrm{~h}$ with $1 \mu \mathrm{g} / \mathrm{ml}$ anti-ShdA PAb (donated by Professor Andreas Baumler) or an isotype control anti-Salmonella polyclonal antibody from our lab (unpublished). Bacteria were added to thermal-stressed $\left(41^{\circ} \mathrm{C}, 1 \mathrm{~h}\right)$ or control $\left(37^{\circ} \mathrm{C}\right)$ Caco- 2 monolayers and incubated for $1 \mathrm{~h}$. Nonadherent bacteria were removed by washing, and adherent bacteria were enumerated as described above.

\section{Cytokine expression in Caco-2 cells following thermal stress and infection}

Influence of thermal stress and $S$. Typhimurium infection on Caco-2 cytokine expression was determined. Following exposure to thermal stress and/or $S$. Typhimurium infection, the profile of cytokines expressed by Caco- 2 cells was examined using the Human Inflammatory Cytokine Antibody Array (Ray Biotech, Norcross, GA) as described by the manufacturer. Briefly, Caco- 2 cells in 24well plates were either subjected to heat treatment $\left(41^{\circ} \mathrm{C}\right)$ for $1 \mathrm{~h}, S$. Typhimurium exposure for $1 \mathrm{~h}$, or heat treatment $\left(41^{\circ} \mathrm{C}, 1 \mathrm{~h}\right)$ followed by $S$. Typhimurium exposure for $1 \mathrm{~h}$ as described above. Following thermal stress or bacterial exposure, all wells including non-treated controls were incubated for $3 \mathrm{~h}$ with DMEM containing gentamicin to kill extracellular bacteria, and to allow time for cytokine production and secretion, after which supernatants were collected and pooled. The $3 \mathrm{~h}$ time point was chosen after an initial range of 1 to $5 \mathrm{~h}$ [42] was tested to determine optimal time required for cytokine release from Caco- 2 cells (data not shown). Supernatants were applied to membranes containing cytokine antibody array (Ray Biotech) for $1 \mathrm{~h}$ at room temperature, and detection was performed with horseradish peroxidase-coupled secondary antibodies and chemiluminescence substrate (Ray Biotech). Array spot densities were determined and compared using Quantity One software (Bio-Rad, Hercules, CA).

\section{Transmission electron microscopy analysis of cell damage, bacterial binding and invasion}

Transmission electron microscopy (TEM) was performed as described by van Tuinen and Riezman [69]. Caco-2 cells were subjected to $1 \mathrm{~h}$ of heat stress $\left(41^{\circ} \mathrm{C}\right)$ and $1 \mathrm{~h}$ of 
$S$. Typhimurium exposure as described above. Media were removed and cells were washed 5 times with PBS. Cells were fixed in $3 \%$ paraformaldehyde containing $0.5 \%$ glutaraldehyde in PBS for $2 \mathrm{~h}$ at $4{ }^{\circ} \mathrm{C}$, washed three times in PBS, incubated in $1 \%$ sodium metaperiodate at room temperature for $1 \mathrm{~h}$, and incubated in $50 \mathrm{mM}$ ammonium chloride for $30 \mathrm{~min}$. Pellets were embedded in 1.5\% agarose and sliced into blocks that were dried in graded ethanol prior to embedding in LR White resin (EM Sciences, Fort Washington, PA). Cells were oven dried to polymerize the resins, which were thin-sectioned and placed on Formvar-coated nickel grids. The grids were air-dried and stained with $2 \%$ aqueous uranyl acetate (Sigma) for 3 min, washed again, and viewed under a transmission electron microscope (EM-400; Philips, Hillsboro, OR).

\section{Statistical analysis}

Each adhesion, invasion and cytotoxicity experiment was repeated on three separate plates, with four replications per plate (12 total replications per treatment). Counts from adhesion and invasion assays, and cytotoxicity values were analyzed using the Generalized Linear Model (GLM) procedure of SAS, and significant differences were determined according to Duncan's test (SAS institute, Cary, NC). Data with a P value less than 0.05 was considered statistically significant.

\section{Competing interests}

The authors declare that they have no competing interests.

\section{Authors' contributions}

$\mathrm{KB}$ and $\mathrm{AKB}$ designed the study. $\mathrm{KB}$ carried out the experiments. $\mathrm{KB}$ and $\mathrm{AKB}$ wrote the manuscript and approved the final manuscript.

\section{Acknowledgements}

Part of this project was supported by Purdue Faculty Scholar funding awarded to AKB and the Agricultural Research Service of the US Department of Agriculture project number 1935-42000-035. Debby Sherman is acknowledged for her assistance with electron microscopy.

\section{References}

I. Finlay BB, Falkow S: Salmonella as an intracellular parasite. Mol Microbiol 1989, 3(12): |833-|84|.

2. Swaminathan B, Barrett T], Fields P: Surveillance for human Salmonella infections in the United States. J AOAC Int 2006, 89(2):553-559.

3. Tauxe RV, Pavia AT: Salmonellosis: nontyphoidal. In Bacterial infections of humans: epidemiology and control Edited by: Evans A, Brachman P. New York: Plenum; 1998:613-628.

4. Gupta A, Fontana J, Crowe C, Bolstorff B, Stout A, Duyne SV, Hoekstra MP, Whichard JM, Barrett TJ, Angulo FJ: Emergence of multidrug resistant Salmonella enterica serotype Newport infections resistant to expanded spectrum cephalosporins in the United States. J Infect Dis 2003, I 88(I I): I707-I7I6.

5. Poppe C, Smart N, Khakhria R, Johnson W, Spika J, Prescott J: Salmonella typhimurium DTI04: A virulent and drug-resistant pathogen. Can Vet J. 1998, 39(9):559-565.

6. Dechet AM, Scallan E, Gensheimer K, Hoekstra R, Gunderman-King J, Lockett J, Wrigley D, Chege W, Sobel J: Outbreak of multidrugresistant Salmonella enterica serotype Typhimurium Defini- tive Type 104 infection linked to commercial ground beef, northeastern United States, 2003-2004. Clin Infect Dis 2006, 42(6):747-752.

7. Finlay BB, Falkow S: Common themes in microbial pathogenicity revisited. Microbiol Mol Biol Rev 1997, 6 I (2): I36- I69.

8. Humphrey T: Science and society - Salmonella, stress responses and food safety. Nat Rev Microbiol 2004, 2(6):504-509.

9. Hinton A, Buhr RJ, Ingram KD: Physical, chemical, and microbiological changes in the ceca of broiler chickens subjected to incremental feed withdrawal. Poult Sci 2000, 79(4):483-488.

10. Isaacson RE, Firkins LD, Weigel RM, Zuckermann FA, DiPietro JA: Effect of transportation and feed withdrawal on shedding of Salmonella Typhimurium among experimentally infected pigs. Am J Vet Res 1999, 60(9): I I55-I I 58.

II. Eshel GM, Safar P, Stezoski W: The role of the gut in the pathogenesis of death due to hyperthermia. Am J Forensic Med Pathol 200।, 22(I): 100-104.

12. Lambert GP: Stress-induced gastrointestinal barrier dysfunction and its inflammatory effects. J Anim Sci 2009, 87(I4_suppl):EIOI-I08.

13. Walia B, Castaneda FE, Wang LX, Kolachala VL, Bajaj R, Roman J, Merlin D, Gewirtz AT, Sitaraman SV: Polarized fibronectin secretion induced by adenosine regulates bacterial-epithelial interaction in human intestinal epithelial cells. Biochem J 2004, 382:589-596.

14. Kingsley RA, van Amsterdam K, Kramer N, Baumler AJ: The shdA gene is restricted to serotypes of Salmonella enterica subspecies I and contributes to efficient and prolonged fecal shedding. Infect Immun 2000, 68(5):2720-2727.

15. Dorsey CW, Laarakker MC, Humphries AD, Weening EH, Baumler A): Salmonella enterica serotype Typhimurium MisL is an intestinal colonization factor that binds fibronectin. $\mathrm{Mol}$ Microbiol 2005, 57(I): I96-2II.

16. Gareau MG, Wine E, Sherman PM: Early life stress induces both acute and chronic colonic barrier dysfunction. NeoReviews 2009, I0(4):el91-197.

17. Burkholder KM, Thompson KL, Einstein ME, Applegate T], Patterson JA: Influence of stressors on normal intestinal microbiota, intestinal morphology, and susceptibility to Salmonella Enteritidis colonization in broilers. Poult Sci 2008 87(9): $|734-| 74 \mid$.

18. Lambert GP, Gisolfi CV, Berg DJ, Moseley PL, Oberley LW, Kregel KC: Molecular biology of thermoregulation: Selected contribution: Hyperthermia-induced intestinal permeability and the role of oxidative and nitrosative stress. J Appl Physiol 2002, 92(4): |750-|76|

19. Shapiro Y, Alkan M, Epstein Y, Newman F, Magazanik A: Increase in rat intestinal permeability to endotoxin during hyperthermia. Eur J Appl Physiol Occup Physiol I 986, 55(4):4I0-4I 2.

20. Dokladny K, Moseley PL, Ma TY: Physiologically relevant increase in temperature causes an increase in intestinal epithelial tight junction permeability. Am J Physiol Gastrointest Liver Physiol. 2006, 290(2):G204-G2I2.

21. Gathiram P, Wells MT, Raidoo D, Brockutne JG, Gaffin SL: Portal and systemic plasma lipopolysaccharide concentrations in heat-stressed primates. Circ Shock 1988, 25(3):223-230.

22. Burkholder KM, Kim K-P, Mishra KK, Medina S, Hahm B-K, Kim H, Bhunia AK: Expression of LAP, an SecA2-dependent secretory protein, is induced under anaerobic environment. Microbes Infect 2009 in press.

23. Eutamene $H$, Bueno $L$ : Role of probiotics in correcting abnormalities of colonic flora induced by stress. Gut 2007, 56(I I): | 495-|497.

24. Zareie M, Johnson-Henry K, Jury J, Yang PC, Ngan BY, McKay DM, Soderholm JD, Perdue MH, Sherman PM: Probiotics prevent bacterial translocation and improve intestinal barrier function in rats following chronic psychological stress. Gut 2006, 55( I I): I553-1560.

25. Ingrassia I, Leplingard A, Darfeuille-Michaud A: Lactobacillus casei DN-II4 00I inhibits the ability of adherent-invasive Escherichia coli isolated from Crohn's disease patients to adhere to and to invade intestinal epithelial cells. Appl Environ Microbiol 2005, 7 I(6):2880-2887.

26. Lee YK, Puong KY: Competition for adhesion between probiotics and human gastrointestinal pathogens in the presence of carbohydrate. Br J Nutr 2002, 88:SIOI-SI 08. 
27. Lee YK, Puong KY, Ouwehand AC, Salminen S: Displacement of bacterial pathogens from mucus and Caco-2 cell surface by lactobacilli. J Med Microbiol 2003, 52(I 0):925-930.

28. Resta-Lenert S, Barrett KE: Live probiotics protect intestinal epithelial cells from the effects of infection with enteroinvasive Escherichia coli (EIEC). Gut 2003, 52(7):988-997.

29. Tuomola EM, Ouwehand AC, Salminen SJ: The effect of probiotic bacteria on the adhesion of pathogens to human intestinal mucus. FEMS Immunol Med Microbiol I999, 26(2): | 37-| 42.

30. Fuller R: Probiotics in man and animals. J Appl Bacteriol 1989 66(5):365-378.

31. Sanders ME, Klaenhammer TR: The scientific basis of Lactobacillus acidophilus NCFM functionality as a probiotic. J Dairy Sci 200I, 84(2):3I9-33I.

32. Delcenserie $\mathrm{V}$, Martel D, Lamoureux M, Amiot J, Boutin Y, Roy D: Immunomodulatory effects of probiotics in the intestinal tract. Curr Issues Mol Biol 2008, I 0:37-53.

33. Macfarlane GT, Cummings $\mathrm{JH}$ : Probiotics, infection and immunity. Curr Opin Infect Dis 2002, I 5(5):501-506.

34. Coconnier-Polter MH, Moal VLL, Servin AL: A Lactobacillus acidophilus strain of human gastrointestinal microbiota origin elicits killing of enterovirulent Salmonella enterica serovar Typhimurium by triggering lethal bacterial membrane damage. Appl Environ Microbiol 2005, 7I( I 0):6I I5-6I 20.

35. Patterson JA, Burkholder KM: Application of prebiotics and probiotics in poultry production. Poult Sci 2003, 82(4):627-63।.

36. Rendon MA, Saldana Z, Erdem AL, Monteiro-Neto V, Vazquez A, Kaper JB, Puente JL, Giron JA: Commensal and pathogenic Escherichia coli use a common pilus adherence factor for epithelial cell colonization. Proc Natl Acad Sci USA 2007, I 04(25): 10637-10642.

37. Ryan KA, Jayaraman T, Daly P, Canchaya C, Curran S, Fang F, Quigley EM, O'Toole PW: Isolation of lactobacilli with probiotic properties from the human stomach. Lett Appl Microbiol 2008 , 47(4):269-274.

38. Johnson-Henry KC, Donato KA, Shen-Tu G, Gordanpour M, Sherman PM: Lactobacillus rhamnosus strain GG prevents enterohemorrhagic Escherichia coli O/57:H7-induced changes in epithelial barrier function. Infect Immun 2008, 76(4): I 340-I 348

39. Bruewer M, Luegering A, Kucharzik T, Parkos CA, Madara JL, Hopkins AM, Nusrat A: Proinflammatory cytokines disrupt epithelial barrier function by apoptosis-independent mechanisms. J Immunol 2003, I 7 I ( I I):6I64-6I 72.

40. Xavier RJ, Podolsky DK: Unravelling the pathogenesis of inflammatory bowel disease. Nature 2007, 448(7 I 52):427-434.

4I. Klimpel GR, Asuncion M, Haithcoat J, Niesel DW: Cholera-toxin and Salmonella Typhimurium induce different cytokine profiles in the gastrointestinal tract. Infect Immun 1995 , 63(3): $1134-1137$.

42. Gewirtz AT, Rao AS, Simon PO, Merlin D, Carnes D, Madara JL, Neish AS: Salmonella Typhimurium induces epithelial IL-8 expression via $\mathrm{Ca}^{2+}$-mediated activation of the NF-kappa $B$ pathway. I Clin Invest 2000, I 05(I):79-92

43. Soderholm JD, Perdue MH: Stress and the gastrointestinal tract II. Stress and intestinal barrier function. Am J Physiol Gastrointest Liver Physiol. 200I, 280(I):G7-GI3.

44. Sikora A, Grzesiuk E: Heat shock response in gastrointestinal tract. I Physiol Pharmacol 2007, 58:43-62.

45. Malago JJ, Koninkx JF, Ovelgonne HH, van Asten FJ, Swennenhuis JF, van Dijk JE: Expression levels of heat shock proteins in enterocyte-like Caco-2 cells after exposure to Salmonella enteritidis. Cell Stress Chaperones 2003, 8(2): 194-203.

46. Le Bacquer O, Laboisse C, Darmaun D: Glutamine preserves protein synthesis and paracellular permeability in Caco-2 cells submitted to "luminal fasting". Am J Physiol Gastrointest Liver Physiol. 2003, 285(I):GI28-GI36.

47. Belles C, Kuhl A, Nosheny R, Carding SR: Plasma membrane expression of heat shock protein 60 in vivo in response to infection. Infect Immun 1999, 67(8):4191-4200.

48. Dziewanowska K, Carson AR, Patti JM, Deobald CF, Bayles KW, Bohach GA: Staphylococcal fibronectin binding protein interacts with heat shock protein $\mathbf{6 0}$ and integrins: Role in internalization by epithelial cells. Infect Immun 2000, 68(I I):632 I-6328.

49. Wampler JL, Kim KP, Jaradat Z, Bhunia AK: Heat shock protein 60 acts as a receptor for the Listeria adhesion protein in Caco-2 cells. Infect Immun 2004, 72(2):931-936.
50. Balaji R, Wright KJ, Hill CM, Dritz SS, Knoppel EL, Minton JE: Acute phase responses of pigs challenged orally with Salmonella typhimurium. J Anim Sci 2000, 78(7): |885-|89|

51. Santos RL, Zhang SP, Tsolis RM, Kingsley RA, Adams LG, Baumler AJ: Animal models of Salmonella infections: enteritis versus typhoid fever. Microbes Infect 200 I, 3( I 4- I 5): I 335-I344

52. Lambert GP: Role of gastrointestinal permeability in exertional heatstroke. Exerc Sport Sci Rev 2004, 32(4): I 85-190.

53. Mehta A, Singh S, Ganguly NK: Effect of Salmonella typhimurium enterotoxin (S-LT) on lipid peroxidation and cell viability levels of isolated rat enterocytes. Mol Cell Biochem 1999, I96(I2): $175-181$.

54. Petrof EO, Kojima K, Ropeleski MJ, Musch MW, Tao Y, De Simone C, Chang EB: Probiotics inhibit nuclear factor-kappa $B$ and induce heat shock proteins in colonic epithelial cells through proteasome inhibition. Gastroenterology 2004, I 27(5): | 474- | 487.

55. Tao Y, Drabik KA, Waypa TS, Musch MW, Alverdy JC, Schneewind $O$, Chang EB, Petrof EO: Soluble factors from Lactobacillus GG activate MAPKs and induce cytoprotective heat shock proteins in intestinal epithelial cells. Am J Physiol Cell Physiol 2006, 290(4): CI0I8-1030.

56. Ait-Belgnaoui A, Han W, Lamine F, Eutamene H, Fioramonti J, Bueno $\mathrm{L}$, Theodorou $\mathrm{V}$ : Lactobacillus farciminis treatment suppresses stress induced visceral hypersensitivity: a possible action through interaction with epithelial cell cytoskeleton contraction. Gut 2006, 55(8): I090-1094.

57. Isaacson RE, Kinsel M: Adhesion of Salmonella typhimurium to porcine intestinal epithelial surfaces: identification and characterization of two phenotypes. Infect Immun 1992 60(8):3193-3200.

58. Clavel T, Haller D: Molecular interactions between bacteria, the epithelium, and the mucosal immune system in the intestinal tract: implications for chronic inflammation. Curr Issues Intest Microbiol. 2007, 8(2):25-43.

59. Banerjee P, Merkel G, Bhunia AK: Lactobacillus delbrueckii ssp. bulgaricus B-30892 can inhibit cytotoxic effects and adhesion of pathogenic Clostridium difficile to Caco-2 cells. Gut Pathog 2009, I(I):8

60. Doron S, Snydman DR, Gorbach SL: Lactobacillus GG: Bacteriology and clinical applications. Gastroenterol Clin North Am 2005, 34(3):483-98

6I. Fajdiga S, Koninkx J, Tooten PC, Marinsek-Logar R: Interference of Salmonella enteritidis and Lactobacillus spp. with IL-8 levels and transepithelial electrical resistance of enterocyte-like Caco-2 cells. Folia Microbiol (Praha). 2006, 5 I (4):268-272.

62. Greene JD, Klaenhammer TR: Factors involved in adherence of lactobacilli to human Caco-2 cells. Appl Environ Microbiol 1994 60( I 2):4487-4494

63. Turner PC, Wu QK, Piekkola S, Gratz S, Mykkänen H, El-Nezami H: Lactobacillus rhamnosus strain GG restores alkaline phosphatase activity in differentiating Caco-2 cells dosed with the potent mycotoxin deoxynivalenol. Food Chem Toxicol 2008, 46(6):2II8-2I 23

64. Hirano J, Yoshida T, Sugiyama T, Koide N, Mori I, Yokochi T: The effect of Lactobacillus rhamnosus on enterohemorrhagic Escherichia coli infection of human intestinal cells in vitro. Microbiol Immunol 2003, 47(6):405-409.

65. Drisko JA, Giles CK, Bischoff BJ: Probiotics in health maintenance and disease prevention. Altern Med Rev 2003, 8: |43-I 55.

66. Maldonado Y, Fiser JC, Nakatsu CH, Bhunia AK: Cytotoxicity potential and genotypic characterization of Escherichia coli isolates from environmental and food sources. Appl Environ Microbiol 2005, 7 I(4): 1890-1898.

67. Bhunia A, Steele P, Westbrook D, Bly L, Maloney T, Johnson M: A six-hour in vitro virulence assay for Listeria monocytogenes using myeloma and hybridoma cells from murine and human sources. Microb Pathog 1994, I6(2):99-II0.

68. Jaradat ZW, Bhunia AK: Adhesion, invasion and translocation characteristics of Listeria monocytogenes serotypes in Caco-2 cell and mouse models. Appl Environ Microbiol 2003 , 69(6):3640-3645

69. van Tuinen $\mathrm{E}$, Riezman $\mathrm{H}$ : Immunolocalization of glyceraldehyde-3-phosphate dehydrogenase, hexokinase, and carboxypeptidase $Y$ in yeast cells at the ultrastructural level. Histochem Cytochem 1 987, 35:327-333. 